\title{
Feasibility of Delaying Removal of Row Covers to Suppress Bacterial Wilt of Muskmelon (Cucumis melo)
}

E. Saalau Rojas, M. L. Gleason, and J. C. Batzer, Department of Plant Pathology, and M. Duffy, Department of Economics, Iowa State University, Ames 50010

\begin{abstract}
Saalau Rojas, E., Gleason, M. L., Batzer, J. C., and Duffy, M. 2011. Feasibility of delaying removal of row covers to suppress bacterial wilt of muskmelon (Cucumis melo). Plant Dis. 95:729-734.

Bacterial wilt, caused by Erwinia tracheiphila, is a major disease of cucurbit crops in the United States. Management of the disease relies on controlling two vector species, striped (Acalymma vittatum) and spotted (Diabrotica undecimpunctata) cucumber beetles. Six field trials were conducted at Iowa State University research farms during 2007, 2008, and 2009 to assess the efficacy of delayed removal of spunbond polypropylene row covers to control bacterial wilt on muskmelon (Cucumis melo). Treatments were (i) row cover removed at anthesis (conventional timing of removal), (ii) covers removed 10 days after row cover ends were opened at anthesis, (iii) covers removed 10 days after bumble bee hives were inserted under row covers at anthesis, and (iv) a noncovered control. In two field trials during 2007 and 2008, the delayed-removal row-cover treatments significantly suppressed bacterial wilt throughout the growing season and enhanced yield

Gilbert in 2008, however, bacterial wilt suppression was equivalent among all three row-cover treatments. No bacterial wilt was observed during three trials in 2009, and there was minimal difference in marketable yield among treatments. Net returns were compared using partial budget and sensitivity analyses. Melon prices and occurrence of bacterial wilt had a strong impact on net returns. Using row covers increased production costs by $45 \%$. In site years in which bacterial wilt occurred, delaying removal of row covers resulted in the highest returns. When bacterial wilt was absent, however, the delayed-removal row-cover treatments had the lowest returns. Results of the sensitivity analysis indicated that delaying removal of row covers for 10 days could be a cost-effective component of an integrated bacterial wilt suppression strategy for muskmelon where bacterial wilt occurs $\geq 50 \%$ of production seasons.
\end{abstract} compared with the noncovered and removal-at-anthesis controls. In
Bacterial wilt is one of the most important diseases of cucurbits in the eastern United States (6). Muskmelon (Cucumis melo L.) and cucumber (Cucumis sativus L.) are highly susceptible, and all cucurbits except watermelon (Citrullus lanatus (Thunb.)) are also susceptible $(17,39)$. In muskmelon, bacterial wilt can cause yield losses as high as $80 \%$ (25).

Bacterial wilt, caused by Erwinia tracheiphila (Smith), is transmitted by striped cucumber beetles (Acalymma vittatum (F.)) and spotted cucumber beetles (Diabrotica undecimpunctata Barber) (39). Transmission occurs when the mouthparts and frass of infested beetles come into contact with fresh feeding wounds on leaves and stems (27). Bacteria enter the xylem vessels, multiply, and block the vascular system. Symptoms include wilting of leaves and vines followed by collapse and death of the plant (40).

Overwintering adult cucumber beetles may appear in muskmelon fields shortly after transplanting, and management of the disease relies primarily on controlling these vectors (14). Insecticides are widely used in cucurbit crops to suppress cucumber beetles $(4,15)$; as many as eight applications are made in a single season (4). However, effectiveness of insecticide-based management is erratic $(4,33,37)$. Furthermore, foliar insecticide sprays may injure pollinators $(4,15)$ and many are highly toxic to aquatic organisms (11). Additional strategies to improve vector control and bacterial wilt suppression include insecticide-spray timing based on cucumber beetle monitoring thresholds $(8,24)$, as well as

Corresponding author: M. L. Gleason, E-mail: mgleason@iastate.edu

* The $\boldsymbol{e}$-Xtra logo stands for "electronic extra" and indicates that a supplementary table appears in the online edition.

Accepted for publication 16 February 2011.

doi:10.1094/PDIS-11-10-0788

(C) 2011 The American Phytopathological Society deployment of perimeter trap crops $(1,37)$, kairomonal baits $(4,19,28)$, and entomopathogenic nematodes (12).

Row covers are spunbonded polypropylene fabrics that protect young plants from harsh weather conditions (41) as well as a range of arthropod pests $(7,35,36,43)$ and facilitate early yield by promoting crop development $(20,21,44,45)$. In addition, they may also protect muskmelon from cucumber beetles and bacterial wilt (32). The covers are typically removed from muskmelon at the beginning of anthesis to allow pollination; under these circumstances, however, they may not provide consistent season-long protection against the disease (32). In preliminary field trials in Iowa, delaying the removal of row covers until 10 days after anthesis provided durable protection against bacterial wilt (22). Vaissiere and Froissart (43) and Gaye et al. (16) also demonstrated that extending the duration of the row-covered period protected muskmelon from late-season frosts, sap-sucking insects, and fruit flies. Later harvest due to delayed fruit set that could result from delaying the removal of row covers could potentially be avoided by supplying bees under the row covers or opening the row-cover ends to provide access for pollinators $(16,43)$.

The objectives of this study were to (i) assess efficacy of delayed removal of row covers for suppressing bacterial wilt on muskmelon and (ii) compare costs and returns of delayed removal to conventional row-cover timing and no row covers.

\section{Materials and Methods}

Six field trials were conducted at Iowa State University research farms in Gilbert and Muscatine (central and eastern Iowa, respectively) in 2007, 2008, and 2009. Muskmelon seed ('Athena') were planted in a greenhouse in 48-cell trays containing a potting mixture $(40 \%$ peat moss and $40 \%$ prepared substrate [Sunshine mix SB300; Sun Gro Horticulture Canada Ltd., Vancouver, Canada] and $20 \%$ coarse perlite). Seedlings were transplanted to field plots on 5 June (Gilbert, 2007), 28 May (Muscatine, 2008), 11 June (Gilbert, 2008), 18 May (Gilbert, 2009), 21 May (Muscatine, 2009), and 22 June (Gilbert, 2009). Within 9-m-long, single-row 
subplots, plants were spaced $0.6 \mathrm{~m}$ apart (15 plants per subplot) on black plastic mulch with drip irrigation; row centers were 2.1 to 2.4 m apart.

Immediately after transplanting, seedlings were covered with polypropylene spunbond row covers (AG-30, Agribon; Polymer Group Inc., Charlotte, NC) supported by wire hoops, and the covers were secured by burying the edges with soil. Treatments were (i) row cover removed at anthesis (conventional timing of removal); (ii) row-cover ends opened at anthesis to enable pollinator access, then cover removed 10 days later; (iii) bumble bee hive (Koppert Biological Systems Inc., Romulus, MI) inserted under one end of the row cover at anthesis, cover resealed, and then cover removed 10 days later; and (iv) no row cover (control). Plots were arranged in four replications in a randomized complete block (2007) or latin square design (2008 and 2009).

Conventional fertilizer was incorporated during soil preparation; application rates were calculated based on crop nutrient requirements and soil test results. Herbicide and fungicide applications followed regional recommendations (11). No insecticide applications were made.

Bacterial wilt and cucumber beetle monitoring. After rowcover removal, plants were assessed weekly until the start of harvest for incidence of bacterial wilt. A plant was considered wilted when symptoms appeared on one or more stems. Bacterial wilt was confirmed visually in the field by testing a subsample of symptomatic plants for the presence of bacterial ooze streaming from xylem tissues (26). Final percent wilt data was subjected to analysis of variance (ANOVA; PROC GLM, version 9.1; SAS Institute Inc., Cary, NC). Area under disease progress curve (AUDPC) values were calculated from average wilt incidence estimates from row-cover removal until first harvest. AUDPC values were analyzed in a one-way ANOVA. Striped and spotted adult cucumber beetle populations were monitored using nonbaited AM Pherocon Yellow Sticky Traps (Trécé Inc., Adair, OK). Four traps were placed in each plot and captured adult beetles of each species were counted weekly from transplant until the end of the season.

Harvest data collection. During twice-weekly harvests, muskmelon fruit were weighed and graded as marketable or nonmarketable according to local direct-market standards. Data for marketable yield were subjected to ANOVA (PROC GLM).

Economic analysis. A partial budget (9) was constructed to analyze costs and returns among treatments. Production costs were estimated using 2010 commercial prices of fertilizer, black plastic mulch, irrigation, seed, pesticide application, and labor. Direct costs of using row covers included the fabric, wire hoops, and labor for installation and removal. In the delayed-removal row-cover treatments, additional costs of labor and bumble bee hives were added as appropriate. Revenue was calculated by extrapolating mean yield per subplot to a per-hectare basis, and multiplying by local wholesale and direct retail prices for muskmelon in central Iowa in 2010 (N. Howell, Iowa State University Horticulture Research Farm, Gilbert, IA., personal communication). The average weight of a marketable Athena muskmelon was assumed to be 2.3 $\mathrm{kg}$ based on local market standards. Net returns were determined by subtracting production cost of each treatment from gross income on a per-hectare basis. Sensitivity analysis across treatments compared several scenarios with varying frequency of bacterial wilt occurrence: $0,5,10,15$, and 20 of 20 years

\section{Results}

Bacterial wilt incidence and yield. Bacterial wilt appeared in the three field trials held during 2007 and 2008 (Table 1). In these trials, use of row covers significantly $(P<0.05)$ suppressed bacterial wilt throughout the growing season. Delaying row-cover removal by 10 days resulted in significantly less bacterial wilt at Gilbert in $2007(P<0.001)$ and Muscatine in $2008(P=0.004)$ than when row covers were removed at anthesis. In these two trials, marketable yield in the delayed-removal treatments was more than double that in the removal-at-anthesis treatment, and removing row covers at anthesis provided little or no advantage in either marketable yield or wilt suppression compared with the noncovered control. In the trial at Gilbert in $2008(P=0.002)$, however, all rowcover treatments suppressed bacterial wilt effectively and resulted in equivalent marketable yield that exceeded that in the noncovered control.

In 2009, bacterial wilt was absent in all three trials and rowcover treatments had little impact on yield (Table 2). At Muscatine, however, marketable yield was significantly higher for the removal-at-anthesis treatment than for either the delayed-removal or control treatments.

Earliness. Impact of the row-cover treatments on earliness (time from transplant until first mature fruit were harvested) varied among site years (Tables 1 and 2). The introduction of bumble bee hives under row covers did not increase earliness when compared

Table 1. Influence of row-cover treatments on bacterial wilt incidence and yield in muskmelon in three site-years in Iowa

\begin{tabular}{|c|c|c|c|c|}
\hline Year, location, treatment ${ }^{v}$ & AUDPC $^{w}$ & Wilt incidence $(\%)^{x}$ & Mean marketable yield $(\mathrm{kg})^{\mathrm{y}}$ & Earliness $^{\mathrm{z}}$ \\
\hline \multicolumn{5}{|l|}{ 2007, Gilbert } \\
\hline Removed at anthesis & $583.3 \mathrm{~b}$ & $58.3 \mathrm{a}$ & $10.9 \mathrm{~b}$ & 57 \\
\hline Delayed removal, ends opened & $87.5 \mathrm{c}$ & $5.0 \mathrm{~b}$ & $23.9 \mathrm{a}$ & 57 \\
\hline Delayed removal, bumblebees & $58.3 \mathrm{c}$ & $6.7 \mathrm{~b}$ & $23.2 \mathrm{a}$ & 57 \\
\hline Control & $1,738.3 \mathrm{a}$ & $75.0 \mathrm{a}$ & $2.8 \mathrm{c}$ & 62 \\
\hline LSD & 265.7 & 17.4 & 3.2 & $\ldots$ \\
\hline \multicolumn{5}{|l|}{ 2008, Gilbert } \\
\hline Removed at anthesis & $5.8 \mathrm{~b}$ & $1.7 \mathrm{~b}$ & $31.5 \mathrm{a}$ & 97 \\
\hline Delayed removal, ends opened & $0.0 \mathrm{~b}$ & $0.0 \mathrm{~b}$ & $34.8 \mathrm{a}$ & 97 \\
\hline Delayed removal, bumblebees & $29.2 \mathrm{~b}$ & $8.3 \mathrm{~b}$ & $42.9 \mathrm{a}$ & 97 \\
\hline Control & $1,405.8 \mathrm{a}$ & $60.0 \mathrm{a}$ & $8.0 \mathrm{~b}$ & 90 \\
\hline LSD & 344.3 & 22.1 & 14.7 & $\ldots$ \\
\hline \multicolumn{5}{|l|}{ 2008, Muscatine } \\
\hline Removed at anthesis & $600.8 \mathrm{a}$ & $55.0 \mathrm{a}$ & $24.3 \mathrm{~b}$ & 64 \\
\hline Delayed removal, ends opened & $134.2 \mathrm{~b}$ & $18.3 \mathrm{~b}$ & $49.4 \mathrm{a}$ & 64 \\
\hline Delayed removal, bumblebees & $64.2 \mathrm{~b}$ & $11.7 \mathrm{~b}$ & $52.1 \mathrm{a}$ & 64 \\
\hline Control & $554.2 \mathrm{a}$ & $53.3 \mathrm{a}$ & $16.8 \mathrm{~b}$ & 57 \\
\hline LSD & 365.8 & 20.7 & 14.3 & $\ldots$ \\
\hline
\end{tabular}

${ }^{\mathrm{v}}$ Removed at anthesis $=$ row covers were removed when first flowers appeared; Delayed removal, ends opened $=$ ends of row covers were opened at anthesi and row covers were removed 10 days later; Delayed removal, bumblebees $=$ a bumblebee hive (Koppert Biological Systems Inc., Romulus, MI) was inserted under one end of the row cover, the row cover was resealed, and the row cover was removed 10 days later; control $=$ no row covers. LSD $=$ least significant difference; means followed by the same letter are not significantly different within row $(P<0.05)$.

${ }^{\mathrm{w}}$ Area under disease progress curve.

${ }^{x}$ Percent wilted plants, rated within 1 week preceding date of first harvest. Final wilt incidence evaluation before first harvest.

${ }^{y}$ Mean marketable weight per treatment (average of four 9-m-long, single-row subplots).

${ }^{z}$ Days between transplant and first harvest. 
with opening the ends at anthesis. In five of the six trials, removing row covers at anthesis enhanced earliness by 3 to 7 days compared with noncovered controls. At Muscatine in 2008, however, harvest of all row-cover treatments began 1 week after the noncovered control. Delaying row-cover removal by 10 days also tended to

Table 2. Influence of row-cover treatments on mean marketable yield in muskmelon in three sites in 2009 in Iowa

\begin{tabular}{|c|c|c|}
\hline Location, treatment ${ }^{\mathrm{v}}$ & $\begin{array}{l}\text { Mean marketable } \\
\text { yield }(\mathbf{k g})^{\mathrm{w}}\end{array}$ & Earliness $^{x}$ \\
\hline \multicolumn{3}{|l|}{ Gilbert $^{\mathrm{y}}$} \\
\hline Removed at anthesis & $116.4 \mathrm{a}$ & 77 \\
\hline Delayed removal, ends opened & $113.4 \mathrm{a}$ & 80 \\
\hline Delayed removal, bumblebees & $109.0 \mathrm{a}$ & 82 \\
\hline Control & $131.0 \mathrm{a}$ & 79 \\
\hline LSD & NS & $\ldots$ \\
\hline \multicolumn{3}{|l|}{ Gilbert $^{2}$} \\
\hline Removed at anthesis & $103.6 \mathrm{a}$ & 62 \\
\hline Delayed removal, ends opened & $105.2 \mathrm{a}$ & 70 \\
\hline Delayed removal, bumblebees & $122.5 \mathrm{a}$ & 71 \\
\hline Control & $109.3 \mathrm{a}$ & 67 \\
\hline LSD & NS & $\ldots$ \\
\hline \multicolumn{3}{|l|}{ Muscatine } \\
\hline Removed at anthesis & $83.8 \mathrm{a}$ & 77 \\
\hline Delayed removal, ends opened & $68.6 \mathrm{ab}$ & 83 \\
\hline Delayed removal, bumblebees & $60.8 \mathrm{~b}$ & 82 \\
\hline Control & $67.3 \mathrm{~b}$ & 80 \\
\hline LSD & 15.4 & $\ldots$ \\
\hline
\end{tabular}

${ }^{\mathrm{v}}$ Removed at anthesis $=$ row covers were removed when first flowers appeared; Delayed removal, ends opened $=$ ends of row covers were opened at anthesis and row covers were removed 10 days later; Delayed removal, bumblebees $=$ a bumblebee hive (Koppert Biological Systems Inc., Romulus, MI) was inserted under one end of the row cover, the row cover was resealed, and the row cover was removed 10 days later; control $=$ no row covers. $\mathrm{LSD}=$ least significant difference; means followed by the same letter are not significantly different within row $(P<0.05)$; NS $=$ not significant.

${ }^{\mathrm{w}}$ Mean marketable weight per treatment (average of four 9-m-long, singlerow subplots).

$x$ Days between transplant and first harvest.

y Transplant on 18 May 2009 and anthesis on 17 June 2009.

z Transplant on 22 June 2009 and anthesis on 13 July 2009. delay harvest by 1 to 7 days compared with the noncovered control. At Gilbert in 2007, however, harvest of row-covered treatments began 5 days earlier than in the control.

Cucumber beetle monitoring. During the period from transplanting to row-cover removal, cucumber beetle captures were minimal except for Gilbert in 2007 and 2008 (Fig. 1). In the other four site-years, the number of captures began to increase only within 3 to 4 weeks of harvest. Both species were found in all siteyears except for Muscatine in 2009, when only striped beetles were captured.

Economic analysis. To extrapolate to a commercial production situation, it was assumed that each row cover would span three rows. This system would substantially decrease labor costs compared with single-row plots used in the field experiment. In total, 25 bumble bee hives were estimated per hectare (http://www. koppert.com/pollination/vegetable-crops/crops/detail/melon/). Row covers raised production costs by approximately $45 \%$, primarily due to the cost of row covers, wire hoops, and labor for installation and removal (Table 3). Delaying row-cover removal and opening row-cover ends increased costs by a further $1 \%$ due to added labor, whereas inserting bumble bee hives raised costs by a total of $18 \%$ due to purchase of bumble bees and labor to install them under row covers.

Site years in which bacterial wilt was present (2007 and 2008) were contrasted to years in which no bacterial wilt was observed (2009). Value of a 2.3-kg, locally grown muskmelon in central Iowa during 2007 to 2009 was assumed to be $\$ 3$ at wholesale and $\$ 6$ for direct-market retail. Melon prices exerted a strong impact on profitability in all site years (Table 3). For site years in which bacterial wilt occurred, average annual returns under both price scenarios were much higher for the delayed-removal strategies than for either the removal-at-anthesis or no-cover controls. The wholesale-price scenario resulted in losses for the latter two treatments. In contrast, all treatments were profitable in 2009, when bacterial wilt was absent; productivity and profitability were much higher than in site years with bacterial wilt. All row-cover strategies reduced projected returns in site years without bacterial wilt.

In the sensitivity analysis (Table 4), the highest annual returns occurred under the no-disease scenario for all treatments, and returns declined as the proportion of years with wilt outbreaks in-
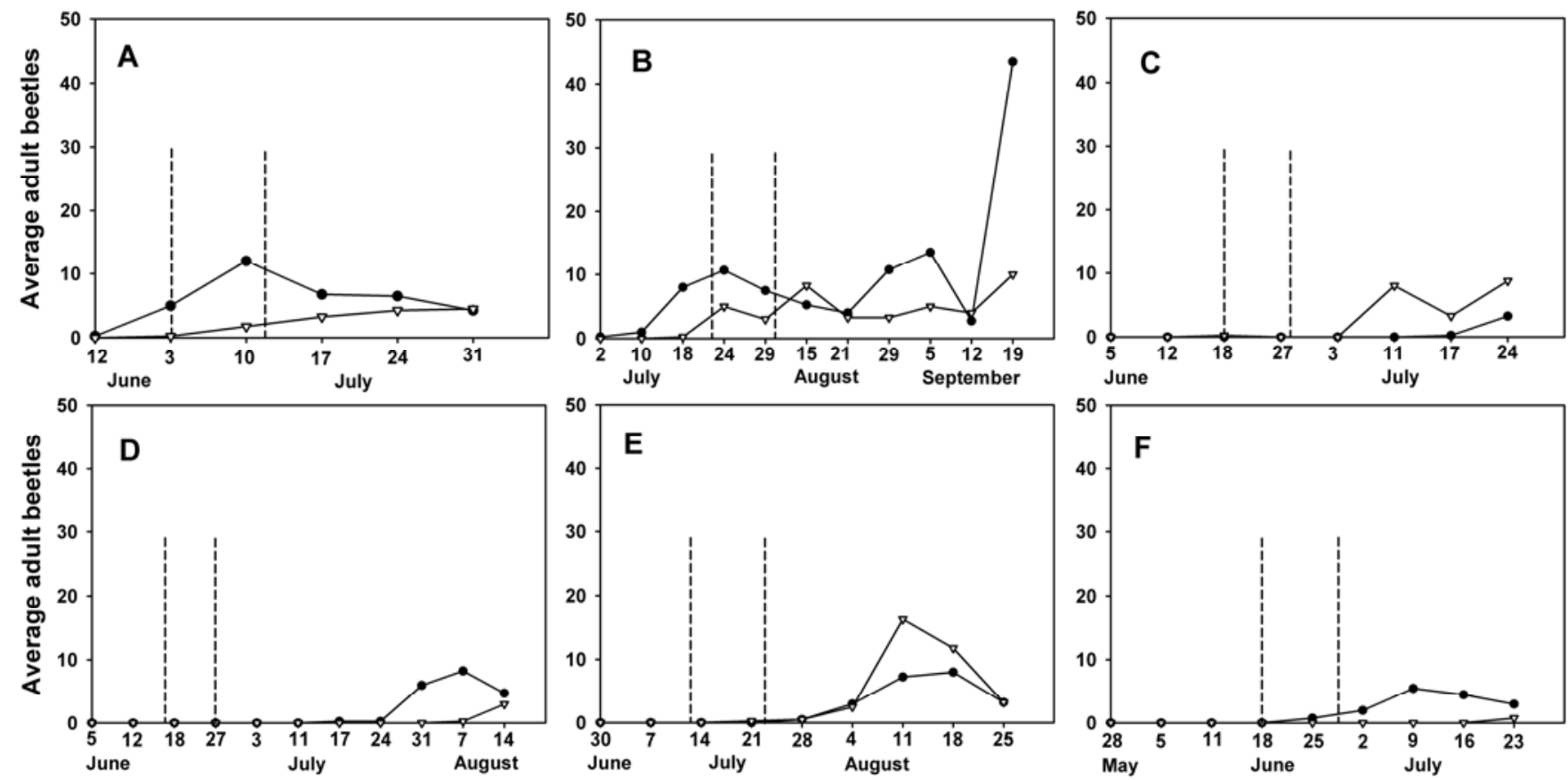

Fig. 1. Striped $(\bullet)$ and spotted $(\nabla)$ cucumber beetles captured on sticky traps from transplant until first harvest in six row-cover trials in lowa: A, Gilbert, 2007; B, Gilbert, 2008; C, Muscatine, 2008; D, Gilbert transplant, 18 May 2009; E, Gilbert transplant, 22 June 2009; and F, Muscatine, 2009. In each graph, vertical lines indicate date of anthesis (left) and 10 days after anthesis (right). 
creased. When bacterial wilt was observed in none or 5 of the 20 years, average net returns in both delayed-removal treatments were slightly lower than for the removal-at-anthesis and noncovered controls. When bacterial wilt occurred in 10 of 20 years, delayedremoval strategies began to yield higher returns than the controls. In this scenario, for example, the open-end treatment was more profitable than the controls at both fruit prices, whereas the bumble bee treatment was profitable only at the direct-market price. When bacterial wilt occurred in 15 or 20 of the 20 years, both delayedremoval treatments yielded the highest returns. When bacterial wilt occurred annually, removal-at-anthesis and noncovered control treatments generated negative annual returns at the wholesale price.

\section{Discussion}

Delayed-removal row-cover strategies provided season-long protection of muskmelon against bacterial wilt. Using delayed-removal row covers could be valuable for growers who lack access to effective insecticides against cucumber beetles, such as organic growers, and those who wish to reduce reliance on insecticides. In an organic trial in Pennsylvania, row covers significantly suppressed bacterial wilt incidence compared with the uncovered control (18). Although timing of removal did not seem to affect wilt suppression significantly, delaying row-cover removal resulted in $13 \%$ less bacterial wilt and higher yield compared with rowcover removal at anthesis (18). Therefore, even a $10 \%$ difference in suppressing the disease may salvage yield and reduce the need for insecticide applications.

The fact that adding 10 days to the row-covered period resulted in season-long suppression of bacterial wilt may be associated with reduction in both vector- and host-associated risks. The highest risk of bacterial wilt transmission occurs during the spring when infested, overwintering cucumber beetles are strongly attracted to cucurbits due to the plants' high concentration of the secondary metabolite cucurbitacin $(3,10,13,14,31,38)$. The additional 10 days of protection could reduce disease risk if (i) fewer first-generation cucumber beetles are present once covers are removed $(2,4,10,14,24)$, (ii) plants advance to a growth stage that renders them less attractiveness to vectors $(13,37)$, (iii) the older plants are more tolerant to infection $(2,29)$, or (iv) some combination of these factors. Clarification of the mechanisms associated with bacterial wilt risk reduction by delayed row-cover removal awaits definitive studies of the ecology of E. tracheiphila transmission.

Efficacy of the delayed-removal strategy might be impacted by its timing during the growing season. For example, the delayedremoval treatments provided much better suppression of bacterial wilt when removal occurred by early July but this difference was not evident when removal occurred 2 weeks later (Gilbert 2008). Delaying the planting date may have eliminated the advantage of delayed-removal treatments compared with removal at anthesis. During the Gilbert 2008 trial, the relatively late occurrence of anthesis may have coincided with a decline in populations of infested overwintering cucumber beetles $(10,14,24,25)$, effectively minimizing the vector-associated risk. The absence of bacterial wilt in 2009 was assumed to stem from high mortality of overwintering cucumber beetles resulting from exceptionally low temperatures during the preceding winter (23).

In addition to preventing bacterial wilt transmission, row covers may enhance yield by protecting plants against environmental extremes $(16,44)$. Plants protected from damaging wind or winddriven rain might be less attractive to cucumber beetles (30). In temperate regions, plant development is accelerated by row covers

Table 3. Partial budget showing costs and analysis of net returns per hectare of muskmelon in two disease-pressure melon-price scenarios ${ }^{t}$

\begin{tabular}{|c|c|c|c|c|c|}
\hline \multirow[b]{2}{*}{ Treatment $^{w}$} & \multirow[b]{2}{*}{$\operatorname{Cost}^{\mathrm{x}}$} & \multicolumn{2}{|c|}{ Bacterial wilt $^{\mathrm{u}}$} & \multicolumn{2}{|c|}{ No bacterial wilt ${ }^{\mathbf{v}}$} \\
\hline & & $\$ 3 /$ melon $^{y}$ & $\$ 6 /$ melon $^{z}$ & $\$ 3 /$ melon $^{y}$ & $\$ 6 /$ melon $^{\mathrm{z}}$ \\
\hline Removed at anthesis & $\$ 16,095$ & $-\$ 926$ & $\$ 14,243$ & $\$ 52,994$ & $\$ 122,082$ \\
\hline Delayed removal, ends opened & $\$ 16,193$ & $\$ 8,390$ & $\$ 32,974$ & $\$ 49,120$ & $\$ 114,433$ \\
\hline Delayed removal, bumblebees & $\$ 19,627$ & $\$ 6,100$ & $\$ 32,981$ & $\$ 45,693$ & $\$ 112,166$ \\
\hline Control & $\$ 11,063$ & $-\$ 4,787$ & $\$ 1,490$ & $\$ 58,889$ & $\$ 128,842$ \\
\hline
\end{tabular}

${ }^{\mathrm{t}}$ Net returns $=$ remainder from subtraction of production costs of each treatment from gross income.

u Mean net returns estimated from 2007 and 2008 field trial results where bacterial wilt was observed.

${ }^{\mathrm{v}}$ Mean net returns estimated from 2009 field trial results where no bacterial wilt was observed.

${ }^{\mathrm{w}}$ Removed at anthesis $=$ row covers were removed when first flowers appeared; Delayed removal, ends opened $=$ ends of row covers were opened at anthesis and row covers were removed 10 days later; Delayed removal, bumblebees = a bumblebee hive (Koppert Biological Systems Inc., Romulus, MI) was inserted under one end of the row cover, the row cover was resealed, and the row cover was removed 10 days later.

${ }^{x}$ Production costs associated with the establishment and maintenance of one hectare of muskmelon using each row-cover treatment.

y Wholesale price estimated for a 2.3-kg locally-grown muskmelon in 2007-2009 in central Iowa.

${ }^{\mathrm{z}}$ Retail price estimated for a 2.3-kg locally-grown muskmelon in 2007-2009 in central Iowa.

Table 4. Sensitivity analysis comparing average annual net returns in five bacterial wilt incidence scenarios during 20 years of production

\begin{tabular}{|c|c|c|c|c|c|}
\hline \multirow[b]{2}{*}{ Treatment $^{\mathrm{x}}$} & \multicolumn{5}{|c|}{ Number of years with bacterial wilt in 20 years $^{\mathrm{w}}$} \\
\hline & $\mathbf{0}$ & 5 & 10 & 15 & 20 \\
\hline \multicolumn{6}{|l|}{ Net returns at $\$ 3 /$ melon $^{y}$} \\
\hline Removed at anthesis & $\$ 52,994$ & $\$ 39,514$ & $\$ 26,034$ & $\$ 12,554$ & $-\$ 926$ \\
\hline Delayed removal; ends opened & $\$ 49,120$ & $\$ 38,938$ & $\$ 28,755$ & $\$ 18,573$ & $\$ 8,390$ \\
\hline Delayed removal; bumblebees & $\$ 45,693$ & $\$ 35,795$ & $\$ 25,897$ & $\$ 15,998$ & $\$ 6,100$ \\
\hline Control & $\$ 58,889$ & $\$ 42,970$ & $\$ 27,051$ & $\$ 11,132$ & $-\$ 4,787$ \\
\hline \multicolumn{6}{|l|}{ Net returns at $\$ 6 /$ melon $^{z}$} \\
\hline Removed at anthesis & $\$ 122,082$ & $\$ 95,122$ & $\$ 68,162$ & $\$ 41,202$ & $\$ 14,243$ \\
\hline Delayed removal; ends opened & $\$ 114,433$ & $\$ 94,068$ & $\$ 73,703$ & $\$ 53,339$ & $\$ 32,974$ \\
\hline Delayed removal; bumblebees & $\$ 112,166$ & $\$ 92,370$ & $\$ 72,573$ & $\$ 52,777$ & $\$ 32,981$ \\
\hline Control & $\$ 128,842$ & $\$ 97,004$ & $\$ 65,166$ & $\$ 33,328$ & $\$ 1,490$ \\
\hline
\end{tabular}

${ }^{\mathrm{w}}$ Simulation of bacterial wilt incidence in 20 years of muskmelon production.

${ }^{\mathrm{x}}$ Removed at anthesis $=$ row covers were removed when first flowers appeared; Delayed removal, ends opened $=$ ends of row covers were opened at anthesis and row covers were removed 10 days later; Delayed removal, bumblebees = a bumblebee hive (Koppert Biological Systems Inc., Romulus, MI) was inserted under one end of the row cover, the row cover was resealed, and the row cover was removed 10 days later; control = no row covers.

${ }^{y}$ Net returns per hectare per year estimated based on a $\$ 3$ wholesale price for a 2.3-kg muskmelon.

${ }^{\mathrm{z}}$ Net returns per hectare per year estimated based on a $\$ 6$ retail direct-market price for a $2.3-\mathrm{kg}$ muskmelon. 
mainly because they create a favorable microclimate for plant development $(41,42)$. Alternatively, when neither harsh weather conditions nor pest-vectored disease pressure are present, row covers may not confer major yield improvement in cucurbits (34). Under certain weather conditions, row covers could even delay harvest by promoting excessive vegetative growth at the expense of fruit development (16). In the present study, removing row covers at anthesis generally enhanced earliness of yield by several days, whereas a 10-day delay in row-cover removal delayed harvest by up to a week compared with the noncovered control. Reliably predicting the extent of harvest delays in muskmelon associated with delayed row-cover removal will require additional field trials over multiple sites and years.

The number of cucumber beetles captured on sticky cards during the period from transplanting to row-cover removal was not consistently related to the level of bacterial wilt that developed in the trials. Although sticky card captures during this period were relatively high during two of the three site-years when bacterial wilt appeared and near zero in the wilt-free trials in 2009, the Muscatine trial in 2008 was an anomaly: row-cover treatments suppressed wilt even though no beetles were collected until well after the row-covered period. This result casts doubt on the ability to interpret the risk of bacterial wilt transmission solely from weekly assessment of sticky-card captures. Additional methods, such as visual surveys of beetle activity in the crop, could provide a supplementary index of the risk of E. tracheiphila transmission (5).

Results of the partial budget analysis suggest that, when bacterial wilt epidemics occurred, the delayed-removal row-cover strategy would be likely to deliver more consistent returns than either the removal-at-anthesis row-cover strategy or the noncovered control. Opening row-cover ends at anthesis was generally more costeffective than inserting bumble bee hives under the covers. Although the analysis did not consider melon-price advantages that could potentially occur from enhanced earliness of harvest, using bumble bees did not advance harvest compared with simply opening the row-cover ends; therefore, the substantial added expense and labor associated with using bumble bees did not appear to be advantageous.

Because bacterial wilt occurs sporadically in Iowa and other northern states in the United States, cost effectiveness of the delayed-removal strategy is likely to be impacted by the frequency of risk of bacterial wilt epidemics. The strategy was economically advantageous in situations when bacterial wilt occurred in $\geq 50 \%$ of growing seasons but constrained returns when wilt was absent or less frequent. Models to predict overwintering survival of cucumber beetles, transmission risk of E. tracheiphila, and occurrence of bacterial wilt epidemics await development. For growers, the advantage of using row covers will depend not only on the likelihood of disease occurrence but also on planting date, melon prices, availability of labor, and viability of effective alternative strategies to manage the disease.

\section{Acknowledgments}

This project was funded by grants from the North Central Region IPM Center and U.S. Environmental Protection Agency Region VII Pesticide Environmental Stewardship Program (PESP). We thank L. Jesse, H. Taber, V. Lawson, and N. Howell for technical advice and assistance; and M. Sigourney, Syngenta Corporation, for providing muskmelon seed.

\section{Literature Cited}

1. Alder, L. S., and Hazzard, R. V. 2009. A comparison of perimeter trap crop varieties: effects on herbivory, pollination and yield in butternut squash. Environ. Entomol. 38:207-215.

2. Brust, G. E. 1997. Seasonal variation in percentage of striped cucumber beetles (Coleoptera: Chrysomelidae) that vector Erwinia tracheiphila. Environ. Entomol. 26:580-584.

3. Brust, G. E. 1997. Differential susceptibility of pumpkins to bacterial wilt related to plant growth stage and cultivar. Crop Prot. 16:411-414.

4. Brust, G. E., and Foster, R. E. 1995. Semiochemical-based toxic baits for control of striped cucumber beetle (Coleoptera: Chrysomelidae) in cantaloupe. J. Econ. Entomol. 88:112-116.

5. Brust, G. E., and Foster, R. E. 1999. New economic threshold for striped cucumber beetle (Coleoptera: Chrysomelidae in cantaloupe in the Midwest. J. Econ. Entomol. 92:936-940.

6. Brust, G. E., and Rane, K. K. 1995. Differential occurrence of bacterial wilt in muskmelon due to preferential striped cucumber beetle feeding. HortScience 30:1043-1045.

7. Bextine, B., Wayadande, A., Bruton, B. D., Pair, S. D., Mitchell, F., and Fletcher, J. 2001. Effect of insect exclusion on the incidence of yellow vine disease and of the associated bacterium in squash. Plant Dis. 85:875-878.

8. Burkness, E. C., and Hutchison, W. D. 1998. Development and validation of a fixed-precision sampling plan for estimating striped cucumber beetle (Coleoptera: Chrysomelidae) density in cucurbits. Pest Manage. Sampl. 27:178-183.

9. Calkins, P. H., and Dipietre, D. D. 1983. Farm Business Management: Successful Decisions in a Changing Environment. MacMillan and Company, New York.

10. deMackiewicz, D., Gildow, F. E., Blua, M., Fleischer, S. J., and Lukezic, F. L. 1998. Herbaceous weeds are not economically important reservoirs of Erwinia tracheiphila. Plant Dis. 82:521-529.

11. Egel, D., Foster, R., Maynard, E., Weinzierl, R., Babadoost, M., Taber, H., Bauernfeind, R., Carey, T., Kennelly, M., Hutchinson, B., and Gu, S. 2007. Midwest Vegetable Production Guide for Commercial Growers 2007. Purdue Extension Publications, Purdue University, West Lafayette, IN.

12. Ellers-Kirk, C. D., Fleischer, S. J., Snyder, R. H., and Lynch, J. P. 2000. Potential of entomopathogenic nematodes for biological control of Acalymma vittatum (Coleoptera: Chrysomelidae) in cucumbers grown in conventional and organic soil management systems. J. Econ. Entomol. 93:605-612.

13. Ferguson, J. E., Metcalf, E. R., Metcalf, R. L., and Rhodes, A. M. 1983. Influence of cucurbitacin content in cotyledons of Cucurbitaceae cultivars upon feeding behavior in Diabrotica beetle. J. Econ. Entomol. 76:47-51.

14. Fleischer, S. J., deMackiewicz, D., Gildow, F. E., and Lukezic, F. L. 1999. Serological estimates of the seasonal dynamics of Erwinia tracheiphila in Acalymma vittata. Environ. Entomol. 28:470-476.

15. Fleischer, S. J., Orzolek, M. D., deMackiewicz, D., and Otjen, L. 1998. Imidacloprid effects on Acalymma vittata (Coleoptera: Chrysomelidae) and bacterial wilt in cantaloupe. J. Econ. Entomol. 940-949.

16. Gaye, M. M., Maurer, A. R., and Seywerd, F. M. 1991. Honey bees placed under row covers affect muskmelon yield and quality. Sci. Hortic. 47:59-66.

17. Gould, G. E. 1944. The Biology and Control of the Striped Cucumber Beetle. Purdue Univ. Agric. Exp. Stn. Bull. No. 490.

18. Hernández, E., and Sánchez, E. 2010. Compost, rhizobacteria, and row covers: a way to manage nutrients and pests in organic production. Penn State Sustainable Agriculture Newsletter. May 2010 http://agsci.psu.edu/ susag/newsletter/May-2010/1-organic-cucurbit

19. Hoffman, M. P., Kirkwyland, J. J., Smith, R. F., and Long, R. F. 1996. Field tests with kairomone-baited traps for cucumber beetles and corn rootworms in cucurbits. Environ. Entomol. 25:1172-1181.

20. Ibarra, L., Flores, J., and Díaz-Pérez, J. C. 2001. Growth and yield of muskmelon in response to plastic mulch and row covers. Sci. Hortic. 87:139-145.

21. Jenni, S. 1996. Predicting Yield and Development of Muskmelon (Cucumis melo L.) under Mulch and Row Cover Management. Department of Plant Science, McGill University, Montreal.

22. Jesse, L., Gleason, M. L., Owens, A., Batzer, J., Lewis, D., and Taber, H. 2007. Use of bumble bees to extend duration of row covers on muskmelon in Iowa. In: (Abstr.) Annu. Meet. Entomol. Soc. Am. San Diego, CA.

23. Koch, R. L., Carrillo, M. A., Burkness, E. C., and Hutchison, W. D. 2005 Observations on the overwintering potential of the striped cucumber beetle (Coleoptera: Chrysomelidae) in Southern Minnesota. Great Lakes Entomol. 38:23-29.

24. Lam, W. F. 2007. An alternative sampling technique for cucumber beetles (Coleoptera: Chrysomelidae) and diurnal beetle activity on muskmelon. J. Econ. Entomol. 100:823-829.

25. Latin, R. X. 1993. Diseases and pests of muskmelons and watermelons Purdue University Extension Bulletin BP-44.

26. Latin, R. X. October 2000. APSnet Features. Bacterial Wilt. http://www. apsnet.org/publications/apsnetfeatures/Pages/BacterialWilt.aspx

27. Leach, J. G. 1964. Observations on cucumber beetles as vectors of cucurbit wilt. Phytopathology 54:606-607.

28. Lewis, P. A., Lampman, R. L., and Metcalf, R. L.1990. Kairomonal attractants for Acalymma vittatum (Coleoptera: Chrysomelidae). Environ. Entomol. 19:8-14.

29. Lukezic, F. L., Sackett, W. M., Fleischer S. J., Orzolek, M. D., and Gildow, F. E. 1996. Influence of the concentration of Erwinia tracheiphila cells on the development of wilt symptoms in field-grown cucumber and cantaloupe plants. (Abstr.) Phytopathology 86:S123.

30. Metcalf, R. L., Metcalf, R. A., and Rhodes, A. M.1980. Cucurbitacins as kairomones for diabroticite beetles. Proc. Natl. Acad. Sci. USA 77:49-37693772 .

31. Mitchell, R. F., and Hanks, L. M. 2009. Insect frass as a pathway for transmission of bacterial wilt of cucurbits. Environ. Entomol. 38:395-403.

32. Mueller, D. S., Gleason, M. L., Sisson, A. J., and Massman, J. M. 2006. Effect of row covers on suppression of bacterial wilt of muskmelon in Iowa Plant Health Progress. doi: 10.1094/PHP-2006-1020-02-RS.

33. Nagent, P. E., Cuthbert, F. P., and Hoffman, J. C. 1984. Two genes for cu- 
cumber beetle resistance in muskmelon. J. Am. Soc. Hortic. Sci. 109:756759.

34. Nair, A., and Ngouajio, M. 2010. Integrating row covers and soil amendments for organic cucumber production: implications on crop growth, yield, and microclimate. HortScience 45:566-574.

35. Natwick, E. T., and Laemmlen, F. F. 1993. Protection from phytophagous insects and virus vectors in honeydew melons using row covers. Fla. Entomol. 76:120-126

36. Orozco-Santos, M., Perez-Zamora, O., and Lopez-Arriaga, O. 1995. Floating row cover and transparent mulch to reduce insect populations, virus diseases and increase yield in cantaloupe. Fla. Entomol. 78:493-501.

37. Pair, S. D. 1997. Evaluation of systemically treated squash trap plants and attracticidal baits for early-season control of striped and spotted cucumber beetles (Coleoptera: Chrysomelidae) and squash bug (Hemiptera: Coreidae) in cucurbit crops. J. Econ. Entomol. 90:1307-1314.

38. Rand, F. V., and Cash, L.1920. Some insect relations of Bacillus tracheiphilus Erw. Sm. Phytopathology 10:133-140.
39. Rand, F. V., and Enlows, E. M. A. 1916. Transmission and control of bacterial wilt of cucurbits. J. Agric. Res. 6:417-434.

40. Sherf, A. F., and MacNabb, A. A. 1986. Cucurbits. Pages 307-311 in: Vegetable Disease and Their Control. Wiley, New York.

41. Soltani, N., Anderson, J. L., and Hamson, A. R. 1995. Growth analysis of watermelon plants grown with mulches and row covers. J. Am. Soc. Hortic. Sci. 120:1001-1009.

42. Taber, H. G. 1993. Early muskmelon production with wavelength-selective and clear plastic mulches. HortTechnology 3:78-80.

43. Vaissiere, B. E., and Froissart, R. 1996. Pest management and pollination of cantaloupes grown under spunbonded row covers in West Africa. J. Hortic. Sci. 71:755-766.

44. Wells, O. S., and Loy, J. B. 1985. Intensive vegetable production with row covers. HortScience 20:822-826.

45. Wolfe, D. W, Albright, L. D., and Wyland, J. 1989. Modeling row cover effects on microclimate and yield: I. Growth response of tomato and cucumber. J. Am. Soc. Hortic. Sci. 114:562-568. 